\title{
AFRICAN PHILOSOPHY AND THE SEARCH FOR AN AFRICAN PHILOSOPHER: THE DEMISE OF A CONFLICTUAL DISCOURSE
}

DOI: http://dx.doi.org/10.4314/ft.v4i1.4

\author{
David A. OYEDOLA \\ Department of Philosophy, Obafemi Awolowo University, Ile-Ife, Nigeria
}

\begin{abstract}
There are contending reasons why the rationale, qualification and justification for becoming an African philosopher are still facing the problem of ontology. One reason, as Didier Kaphagawani posits, is premised on the challenges by anthropology and colonialism $(1986,86)$. Given Oruka, Makinde, Oladipo, Oke, and Hallen's perception of these challenges, they concede that these challenges gave birth to the postcolonial search for a distinct African identity. On the one hand, D. A. Masolo's submission that because "Africa cannot be re-subjectivised; hence, an identity which is peculiarly African is impossible" (1997, 283-285) downplays the concession of Kaphagawani, Oruka, et al. Moreover, there tend s to be agreement among certain philosophers who have devoted their time promoting Africana philosophy and culture-oriented discourse in Africa like Outlaw, Cabral, Fanon, Makinde, Oladipo, Oke, Hallen, Horton, etc., that "the Western discourse on Africa and the response to such discourse" (MASOLO 1994, 1) led many African philosophers like Nazombe, Okpewho, Tempels, Nkrumah, Nyerere, Senghor, Cesaire, Awolowo, Mandela, etc., to react using socio-political and academic means to establish a distinct African philosophical paradigm which craves for the re-subjectivisation of Africa. By implication, the response to the Western discourse on Africa, as Outlaw, et al, opine, lend credence to (a) the rationale for the qualification and justification to be an African philosopher; (b) the existence of African philosophy, and (c) the modality of doing philosophy in Africa. Nevertheless, the problem with Outlaw, et al, on one hand, and D. A. Masolo, on the other, is the failure to recognize that any philosopher need not be of African descent or blood before he can make a meaningful contribution to address the problems facing the development of Africa in all spheres of life. This is possible in as much as there is an adequate understanding of the subject under discussion or what it means to do African philosophy. It is this failure or weakness that we shall explore in this essay.
\end{abstract}

Keywords: Africa, African Paradigm, African Philosophy, African Philosopher, Identity

\section{Introduction}

If acknowledging Paulin Hountondji's concession that "what is needed in Africa is to aghelp the people and their lives to master and capitalize on the existing knowledge,

${ }^{2}$ which the local users do not have or know" $(2006,535)$ would aid culture-oriented discourse in Africa, then, this study sees ethnophilosophy (which is the study of the 
most general ideas and views in the African philosophy) as mistaken and misdirected. Part of what this study attempts to explicate are; (i) why the late twentieth century appears to be marked by a deep intellectual discomfort about the ways in which the Western thought has succeeded in framing an understanding of the world of the Africans (or 'Others')? By this framing, Africa was wrongly categorized into a disease continent. This disease was premised on the religious, savagery, perceptual, unscientific, pre-logical and oral perception of the African worldview, culture, language and philosophy. This disease has further nullified the African reality in terms of cultural expression and representation. This paved way for the notion that the African understanding of their world was not in existence prior to the Western invasion. This invasion, as the Western thought conceives, brought various positives to Africa. For the Western anthropologists, this invasion opened the mind/eyes of Africa and the Africans to socio-political emancipation and development in arts, literature, science and philosophy. One symptom revolves around the current philosophical debates which see either a dramatic end to, or a winding down from the Western concept of modernity and discovery of what the Western thought calls 'others'. Another symptom of this disease is the view that there was no 'modernity' in the 'others' as the Western thought seems to have explained and it was their contact with Africa, they think that actually brought modernity to the 'others'.

As a derivative of the Western conceptual characterization of the 'Others', African philosophy, according to Bruce Janz could become misconstrued as the "philosophy produced by African people: philosophy which presents African worldviews or philosophy that uses distinct African philosophical methods" (JANZ 2009, 74-75) to respond to the Western insult or negative characterization of Africa. Thus, this philosophical model differs from American pragmatism which emphasizes the sufficient working of any view/belief which one holds; European continental philosophy which emphasizes phenomenology ; British empiricism which places importance on analyticity where knowledge is ultimately sensed; and Paulin Hountondji's characterization of what "knowledge and development" (2006, $535)$ should be. In view of the above, Olúfémi Táíwò's assertion that "the production of academic studies of the political philosophies of Africa's post-independence leaders due to the pressure of direct problems of governance" $(2006,243)$ should not be ignored. Because of Appiah's nullification of the idea of race and Masolo's opposition to identity which Olúfémi Táíwò criticizes. This study will afford us the opportunity to delineate the foundation for the search of African philosophy and an African philosopher. It will further afford us the opportunity to have the understanding of who, in the perspective of this study may qualify as an African Nphilosopher as different from Hountondji, Appiah, and Masolo's presentations. $\checkmark$ Hence, certain conditions will be emphasized as the grounds for the rejection of a ogpeculiar African philosophical paradigm; the common human family, common race, c cosmopolitanism, globalization, etc., are examples of concepts used to reduce the idea of an African philosophy to absurdity. However, it is expected that the notion 
that anyone concerned with truth and accuracy about African philosophy should ordinarily avoid using the term "African", "tribe" or "race" should be addressed. Such individuals should endeavor to use a formidable characterizing factor to establish the qualification for an African philosopher. An African philosopher should be expected to enhance the development of a distinct African philosophical paradigm by any means possible. It is insufficient to conclude that anyone who desires to write on topical and problematic issues in African philosophy does not need to be an 'African' by blood or race. Any view that draws such a conclusion without asserting the importance of African origin of an African philoso pher is an attempt to deny the importance of a peculiar cultural identity of Africa or various cultural identities within Africa and African people. It is noteworthy that the denial of the writings of those who are Africans on issues pertaining to the development of philosophy in Africa may not aid the development of Africa. Admittedly, to deny anyone of the ability to contribute to African philosophy and development will be accepted if and only if the writings fail to represent the political, cultural and philosophical conditions of the Africans.

Second, (ii) what is it that disqualifies ethno-philosophy from being a representation of the totality of African philosophy? That is, why is it impossible to simply take or regard ethno-philosophy as a contribution to philosophy - a discipline which accommodates the first-order and second-order levels of discourses? It is simply because ethno-philosophy lacks the generally accepted ingredients of philosophy such as critical rigor, argumentation and analysis. The supposition therefore is that any discourse and any philosopher that shall qualify as philosophy/philosopher, in addition, must have these philosophical ingredients. Granted that philosophical rigor qualifies a discourse as philosophy and a discussant as a philosopher, what then makes philosophy African, and a discussant African philosopher? This issue which Uduma $(2014,135)$ refers to as the Africanness of a philosophy criterion seems to remain unsettled among African philosophers. We shall give it attention in this paper.

\section{The Quest for African Philosophy and for African Philosopher}

The various attempts to explicate the emergence of African philosophy and to affirm the peculiar nature of a distinct African philosophical paradigm has pervaded the socio-political and cultural discourse in Africa starting from the latter part of the twentieth century. Similarly, the various attempts to redefine and justify who qualifies as an African philosopher have endeared the analytical skills of many philosophers in Africa and in the Diaspora. The reason why these attempts have ensued and the purpose they are meant to achieve are still under rigorous discussion

Mtoday. Some African scholars starting from Kwasi Wiredu to Odera Oruka, Nazombe $\Omega$ to V.Y. Mudimbe, Paulin Hountondji to Didier Kaphagawani, Peter Bodunrin, to coMoses Makinde Olubi Sodipo to Innocent Onyewuenyi, Kwame Nkrumah to $\approx$ Kwame Gyekye, Julius Nyerere to Leopold Senghor, Niyi Osundare to Moses Oke, Barry Hallen to Segun Oladipo, Placid Tempels to Alexis Kagame, Frantz Fanon to 
Amilcar Cabral, Nelson Mandela to Sékou Touré, etc, have found the position that it was the description of Africa and Africans by Levy Bruhl, that they lack ratiocination (logic) which presented African philosophy as nonsensical. Similarly, Robin Horton's rejection of the Bruhlian negative disposition cannot be ignored. The reason is because "the African condition or mentality is not essentially or fundamentally symbolic or ritualistic (not religious, oral-dependent, perceptual, etc.,) in character" (HALLEN 2002:18), and that "those who rejected the theoretical thinking of African philosophy (or, its distinct philosophical paradigm) have failed to see the correlatives in other cultures because they are blinded by a difference of idiom" (HORTON 1998, 181). Furthermore, he (Hallen) believes that "it was the quest to have an autochthonous, independently minded analytic tradition" $(2002,19)$ that gave birth to the debate about the existence of African philosophy and a paradigm to enhance the development of African socio-political discourse. Moreover, Barry Hallen's position has gained credence from some scholars that African philosophy started as (i) a cultural and an academic response to the proposition that Africans lack ratiocination, and (ii) a reactionary medium to undermine or relegate the views that African philosophy and African philosophical paradigm contains pre-logical, savagery, religious, perceptual, oral (un-writing) traits, etc.

In this respect, some of the things which many philoso phers in Africa and the Diaspora have not denied, are as follows; (i) the role which anthropology played in waking African socio-political, cultural and philosophical discourse from their slumbers: where the lack of ratiocination was seen or categorized as "insult" to the African destiny prior to, during and after the European incursion into Africa; and (ii) the role which colonialism played in the socio-political, cultural/traditional and economic life of Africa and Africans. It is not surprising that the effects, impacts and influence of anthropology led by Levy Bruhl, etc., and colonialism led Africa and Africans to the search for a post-colonial identity-a distinct transformation from the first-order level to second-order level of cultural/philosophical analysis. This is with a view of rescuing Africa from the economic, academic, and mental steriotype or stamp placed on Africans. This attempt, to an extent, is responsible for Kwasi Wiredu's thought that African philosophical worldviews employ personal rather than impersonal models of causal explanation of human community and the world in order to argue out the view that "Western anthropologists have apparen tly been unfamiliar with the folk thought of the African culture" (WIREDU 1998, 193). It, therefore, seems that Wiredu's criticism of Robin Horton's problematic comparison of Africa with the West as lacking legitimacy is appealing, but Wiredu's view appears to stand against Hountondji's pluralism where African thought must be seen to be attending to the issues of universal significance rather than folk philosophy. $\checkmark$ However, Wiredu's, Horton's and Hountondji's views cannot make this study to Ldeny Barry Hallen's submission that "African philosophy still has an important role coto play insofar as such elements that pervades African philosophical discourse or inquiry should be subject to critical analysis and reflective evaluation of the evidence 
underlying their development" (HALLEN 2002, 21). This is an outright albeit indirect rejection of ethno-philosophy.

Here again, it is important we find Marlene Van Niekerk's contention that "in the light of the history of anthropology and its mode of othering - which constitute a rationalization for the phases of colonial oppression - it ought not to be surprising that the debate about the term "African Philosophy" as an ongoing affair," $(1998,73)$ is very interesting and encouraging. Though African philosophy is an ongoing affair, as Marlene Van Niekerk, reiterates, it is also considered as an unending affair with the West's negative conceptualization or categorization of Africa as oral, savagery, religious, and pre-logical.

On the one hand, the basis for such contention, as Marlene Niekerk opine, is that "it is debated precisely because the term "African philosophical paradigm" also denotes an instance of essentialist or typological othering: it is a term that assumes that "there is a way of thinking or a conceptual framework that is uniquely African and which is at the same time radically unEuropean" (1998, 73). Niekerk's conclusion is that the term "others" which continues to be fiercely criticized is a sign that the time is long past and that the "Other" and "their thi nking" could be "arrested" and "held up" by the West as objects of study $(1998,73)$. For him, the terms "African Thinking" and "African Philosophy" would certainly not have had such a negative resonance if they did not have a history $(1998,53)$. It is from this historical basis that some other radical African scholars like Fanon etc, thought that "African philosophy" started or began.

On the other hand, Emevwo Biakolo's view that "the relations between the knowing subject and its object, in any account of the epistemological process, have occupied the Western philosophy from the time of Plato, and most especially with the advent of both Cartesian and Lockean empiricism" $(1998,1)$, represent how the West saw their incursion into Africa as help and not a means of destruction. In a different light, to be an object of study is, in most cases, denigrating. Although in the field of philosophy, Biakolo asserts that "the central concerns have been with the individual subject as such, it was not long before the influe nces of these interpretations of subject/object relations began to make themselves felt in the much younger discipline of anthropology" (1998, 1). Biakolo's view/assertion has a damaging implication; anthropology has endeared some anthropologists like Levy Bruhl, Stanislav Andreski, and C. G. Jung to view Africa and Africans as lacking ratiocination: that is, pre-logical, savages, primitives, mystical, unscientific, perceptual, oral and religious. The perception/view of Levy Bruhl, as an anthropologist, is that "the primitive (African) mind does not differentiate the supernatural from reality but rather uses "mystical participation" to manipulate the

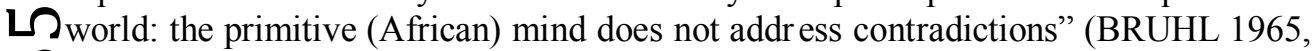
$\mathbf{S}$ 43). However, in consonance with the pattern of growth and development of the new coscience of culture, which has its historical basis in epistemology until anthropology ¿emerged, Biakolo says, "the determining factor here is always about "race"” (1998, 1). If Biakolo's analysis is correct, then, it suffices to say that the fundamental 
dichotomy between the West and the Africans given the nature and introduction of anthropology on the subject/object relations was used to carry out a study on the Africans, making Africans and Africa objects of study. This, to a great extent, affected the identity of the Africans. According to Biakolo, "this anthropological attitude reveals ingenuity; but this (ingenuity) goes further to confirm the political project behind the Western construction of the cultural and philosophical paradigms of the "Other"" (1998:1).

If it is the case that the anthropological attitude reveals ingenuity (which seem to deny the existential status of a distinct African philosophical paradigm), as Biakolo reveals, then, Kwame Appiah's concession that there are no races: there is nothing in the world that can do all we ask race to do for us (ILLUSIONS OF RACES, 1992, 45) should not be surprising. He (Appiah) advanced this submission in his other works like [Color Conscious: The Political Morality of Race] (1996), [The Ethics of Identity] (2005), [Cosmopolitanism: Ethics in a World of Strangers] (2006), and gain credence/support from D. A. Masolo's concession that identity is impossible in "African Philosophy and the Postcolonial: Some Misleading Abstractions about Identity" (1997). There are a host of reasons why Appiah's and Masolo's concessions should not be surprising to many who care to advance African philosophy and believe in a distinct African philosophical paradigm. These reasons are as follows: (i) by virtue of their (Appiah's and Masolo's) denials, they have jettisoned the distinctiveness of African philosophical paradigm; (ii) as a derivative of (i), there are certain Africans of African descent who do not see anything worthwhile in a distinct African philosophical, literary and cultural paradigms; (iii) it will not be the case that it was only non-Africans (anthropologist like Levy Bruhl) who denied Africans of their distinct philosophical, literary (or, language) and cultural paradigms; therefore, (iv) a distinct African philosophical paradigm (call it ethno-philosophy) cannot be seen as effective or worthy to exist outside a distinct/common human philosophy, family or race. As it appears, Appiah's and Masolo's submissions out rightly deny the existence of African philosophy as a distinct field of philosophical inquiry.

Appiah's and Masolo's views, though, appear to be disturbing and discouraging; D.N. Kaphagawani's examination of the way in which African philosophy started brews fresh air and brings encouragement. Following Wiredu, Oruka, Nazombe, and V.Y. Mudimbe, Kaphagawani maintains that "though "gathering momentum", African Philosophy is, as accepted by philosophers in Africa, still in its embryonic stage" $(1998,85)$. Kaphagawani's understanding is that African philosophy should be allowed to thrive as many flowers should be allowed to bloom. In allowing many flowers to bloom, in Kaphagawani's view, we would only be promoting debates, critical analyses and self-criticisms when grappling with the

$\mathbf{L}$ numerous issues in contemporary Africa which are amenable to philosophic cotraditions and not just to create traditions. One implication/interpretation of this

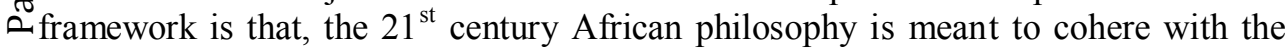
second-order level of philosophic activity which entails rigour, analyticity and 
criticism. He (Kaphagawani) pointed out three evils which must be eschewed in order for constructive analyses, possible debates and critical analysis to c ome out of Africa in the $21^{\text {st }}$ century. These evils, Kaphagawani calls them the names, authoritarianism (permanent control of all aspects of life, politics included, the things which compel people to do things against their will); anachronism (systems or principles outliving their suitability and utility); supernaturalism (the tendency to establish supernatural foundations for a natural code of conduct) $(1998,86)$.

On the question, why African philosophy? Kaphagawani highlighted the conditions that gave rise to its emergence. His position is that the question "What is African Philosophy?" has preoccupied scholars in Africa for several decades, basically two reasons: One, the attempt to falsify certain anthropological thesis by Levy Bruhl, which denied Africans south of Sahara properties of ratiocination and its cognates due to the apparent primitiveness of these people's mentality. That is, anthropologists of a Levy Bruhlian persuasion presented Africans as incapable of evolving a scientific, logical and reason-oriented culture. Two, the role which colonialism played in Africa coupled with the post-colonial quest/search for a distinct African identity. And three, given the perception that the Europeans colonized Africa, this has led to the view that African metal culture was long destroyed; and this has led Africans into searching for post-colonial identity. For Kaphagawani, the anthropological challenge and the colonial challenge are the factors which resuscitated or motivated, for good or ill, philosophers in Africa to ask the question, "What is African Philosophy?" $(1998,86)$

As acknowledged by some African philosophers, the history of African philosophy can be traced to the evils that colonial dispensation brought on Africa. For some other philosophers like Cabral, Fanon, Horton and Serequeberhan, the post-colonial quest for a distinct African identity played a significant role in the emergence of a distinct African philosophy or African philosophical paradigm. But, as Didier Kaphagawani opined, the quest for the post-colonial African identity is solely responsible for this protracted dispute on the question of "Why African Philosophy". The second reason for the debate or the dispute on the question of "Why African Philosophy", has been traced to the very nature of the discipline of philosophy itself (KAPHAGAWANI 1986, 86-87).

Some scholars have acknowledged the types of philosophical frameworks which are used in identifying the different ways of doing African philosophy. These types of philosophical frameworksmay also qualify as the theories of remaking Africa. These frameworks, they refer to, as ethno-philosophy, philosophic sagacity, nationalistic-ideological philosophy and professional philosophy. In other words, these are the approaches of doing African philosophy. Furthermore, philosophers like Wiredu, Oruka, Kaphagawani, Makinde, Bodunrin, etc, identified the classification $\boldsymbol{L}$ of African philosophy into two different schemata. These classifications represent the cofollowing; one, the four-rung Orukan framework which Okpewho and Nazombe

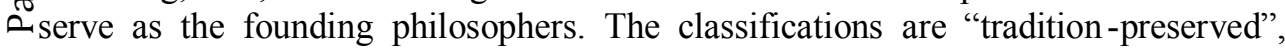
"tradition-observed", "tradition refined" and "tradition revised". And, two, there are 
two fundamental notions which underlie the knowledge of how to do African philosophy. These two ways, Segun Oladipo (2008) calls the traditionalist and the modernist understanding of African philosophy and African philosophical paradigm, while Barry Hallen (2002) calls these two ways, the culturalist and universalist distinctions to doing African philosophy and understanding African philosophical paradigm. The traditionalist (Oladipo 2008) or the culturalists (Hallen 2002) account to doing African philosophy is an encounter which Africa should not forget, given the colonial experience. This form of experience, according to the traditionalists or culturalists, inflicted two things on Africa; political subjugation and economic exploitation. Similarly, according to the 'traditionalists' or 'culturalists' account, colonialism had its ideology of legitimation. This is embedded in the denigration of African beliefs, cultural practices, especially religion, and social institutions. However, traditionalist/culturalist, as trends using the same methodology, see African philosophy as the collective world view of Africans concerning man, nature and society. The modernists (Oladipo 2008) or the universalists (Hallen 2002) account to doing African philosophy and understanding African philosophical paradigm refers to a form of intellectual inquiry which is ratiocinative, critical and individualistic, using modern logical and conceptual techniques. The traditionalist/culturalist, as factors using the same modality, has close affinity with ethno-philosophy while the modernist/universalist, as factors using the same modality are close affinity with critical, analytical or professional philosophy.

In order to address the four trends to doing African philosophy as different from Oladipo and Hallen's two ways of doing African philosophy, D.N. Kaphagawani acknowledges ethno-philosophy as a conception that sees African philosophy as communal thought ... as opposed to seeing it as a body of logically argued thought of individuals. Ethno-philosophy is premised on the assumption that "there is a metaphysical system, and an ideology, embodied in the traditional wisdom, the institutions and the language of Africa" (1998, 89). For him, many anthropologists are attracted to this approach because of the conceptual problems that are embedded in it. They are the problems of authenticity and the problem of differences, which are attracted to ethno-philosophy. Philosophic sagacity, for Kaphagawani, is different from the ethno-philosophical approach. It underscores the thoughts of individuals in a community. It is a second-order philosopher, as conceived by Odera Oruka. Nationalistic-ideological approach is a method which tries to evolve a new and, if possible, unique political theory based on the traditional African socialism and familyhood. Professional philos ophy, on the other hand, sees what passes as African philosophy as that which is "engrained with argu ment and criticism" $(1998,95)$.

$\infty$ The quest to reveal what may actually be the original historical $\mathbf{S}$ basis/condition of African philosophy, for some philosophers like coKaphagawanishould aid our concession that the presentation of the nature of this Whistoricity is exactly how colonialism, anthropology, and the post-colonial quest for identity has allowed us to perceive and interpret ideas and things. Thus, (i) we cannot 
subscribe to the fact that there were no traces of philosophical tendencies in Africa before the Western anthropological study of Africa; and (ii) there were genuine representations of the distinctiveness of African philosophy from Western philosophical discourse. By implication, if we subscribe to the fact that the West invented the African orientation concerning philosophical discourse, it will suggest that there was no philosophical discourse in Africa prior to the European invasion, and that the anthropological study paved way for the discovery of Africa out of nowhere. Africa does not need to dwell on the post-colonial quest for an identity despite the fact that there are many cultures evolving in Africa.

The fundamental issue of the lack of ratiocination raised by Levy Bruhl in his skepticism about African philosophy and the responses by Hountondji and others have been addressed in the following works, African Philosophy: The Demise of a Controversy (MAKINDE 2010); Is There an African Philosophy, (RUCH 1974), and On Delimiting African Philosophy and the Equalization Scheme ( IBOUT 2011). Makinde's, Ruch's and Ibout's aim is not to reignite the tendencies of starting African philosophy all over again but to start doing African philosophy beca use it genuinely exists. One implication of Makinde's, Ruch's and Ibout's claims is that, since the satisfaction of the logic of modus ponens and other philosophical tendencies are already embedded in certain African languages (i.e., Yoruba language), this signifies the presence of philosophical climate. We should no longer dwell on the question whether there is African philo sophy, as Makinde and Ibout put it, we should start doing it.

\section{The Conflicting Positions on who qualifies as an African Philosopher}

Varying discussions have ensued about two respective views; how to do African philosophy and how to arrive at the qualification for becoming an African philosopher. It is pertinent we say that different or opposing answers are warranted since there have been varying discussions in different respects. However, certain problems arise based on this contending answers: (i) which of the contending views with respect to qualification would sufficiently lead us to the authentic representation of African philosophy; (ii) how do we get a paradigm with which we can arrive at how an African philosopher can be/should be/ought to be known; and (iii) do we, in actual fact, need an African philosopher to be able to carry out a discourse on any subject in Africa? The response to problem (i) gains credence from Appiah, Masolo and Samuel T. Segun. Problem (ii) has been answered by Uduma O. Uduma, Hountondji , and Oke. The response to problem (iii) lay in the attempt to be made by this study to give an answer which would not beg the question. It is important we admit, in the case at hand, that a sufficient answer might be difficult to arrive at. The reason is precise: the provision of qualification for being an African philosopher has

$\checkmark$ been placed on certain restrictions. To begin with, any opinion which tends to present ofa concise understanding of who should qualify or ought to qualify as an African $\approx$ philosopher from the African perspective may be termed Africanism or relativistic. Another perspective may suffice to place a fundamental difference on, who under a 
genuine guise should become an African philosopher, and who, based on the possession of required philosophical skills, articulation and having no destructive tendencies toward Africa, should become an African philosopher. Admi ttedly, the genuineness of purpose is the only problem to this perspective. This is because there is a consistent restriction on who an African is, which is first and foremost, by blood or ancestral lineage. The dire implication of the above perception is that, whoever is not African by blood or ancestry, should not/cannot qualify as African philosophy from (i) the holistic; (ii) the cultural; and (iii) the traditional points of view, thereby forsaking or neglecting the professional aspect of doing philoso phy in any region of the world. The central problem to the above issues and implications is presented by Samuel T. Segun: "the concerns of philosophy all transcend geographical boundaries" $(2014,106)$.

In his work "Knowledge and Development Issue", Hountondji asserts that "not so long ago, there was a widespread belief that the only way for Africans to do African philosophy was to philosophize about Africa" (2006, 529). For Hountondji, "what he accepted least, however, was the way African scholars themselves took up this project uncritically as handed down to them by this tradition" $(2006,529)$. His problem is the failure of many African scholars to ask whether such investigation were suitable for anything other than feeding the curiosity and other in tellectual and even non-intellectual needs of the Western readership. Thus, to philosophize as an African for African sake in an uncritical and un-universal way, or in an ethnophilosophical manner, as Hountondji says, was not the standard one $(2006,530)$. As Hountondji mildly put it:

I wanted to make it clear that this kind of investigation amounted to creating a new standard of philosophical practice specific to Africa and such other areas as are traditionally considered research fields for ethnographers and anthropologists. This new standard was one that was bound to hinder the African philosopher or, for that matter, the so-called primitive or semi-primitive philosopher from tackling issues of a universal meaning and significance. (2006, 529-530)

If we are to accept whether tentatively or sufficiently, what Hountondji has said as valid and sound, African philosophy and African philosophical paradigm will be considered as null and void. Why? Africans will be dwelling on a set of assumptions systematic enough to be considered, as it often is, as a "system of thought" without a pluralistic significance but premised on a problematic view of unanimism. Unanimism, as Hountondji sees it, is the original problem of anthropology. It makes people, individuals or societies studied by anthropology to want to respond, attack, and create their own identity. For him, unanimism, which refers to the

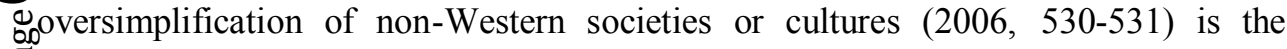
๘problem with Africans erecting a distinct philosophical paradigm. In More's explication, "to deny that "race" (or African philosophy) exists, is to create a 
problem, and it cannot be ignored or simply wished away by declaring its nonexistence: it needs to be confronted as part of the Africa $n$ and world reality" (MORE 1998, 371).

However, forasmuch as we may not want to take ethno-philosophy as the philosophy representing Africa and the Africans, it is inconclusive and incoherent to assert that Africa and African scholars should not erect or display a distinct philosophical paradigm given that there is every reason to employ a universal, global, pluralistic, or relativistic approach in philosophical study. Thus, no restriction can be adequate or sufficient to help situate the African contextual proble ms by certain people. How do we make being an African philosopher paramount than doing African philosophy? Hountondji, Appiah and Masolo's failures are irredeemable. This is because they may have forgotten that there are European Continental philosophers, American pragmatists, European analytic philosophers, British empiricists, Oriental philosophers, Chinese philosophers, etc. Since Hountondji's pluralism "acknowledges the fact of diversity, including diversity of opinion and belief in every human society" (KNOWLEDGE 2006, 530-531), and Appiah asserts that "if the eight million people of Negro blood in the United States of America must soon come to realize that if they are to take their place in the van of PanNegroism, then their destiny is not absorption by the white Americans" (ILLUSIONS 1992, 29), then, having African philosophers searching for a distinct African philosophical paradigm is possible, permissible and welcomed. What we may take from Hountondji's idea of pluralism is the view that certain individuals will be identified as genuinely or typically identity propagators and defenders while some others will be identity deniers. However, race and identity may have been rejected by Kwame Appiah in the [Illusions of Race] (1992), [Color Conscious: The Political Morality of Race] (1996), [The Ethics of Identity] (2005), [Cosmopolitanism: Ethics in a World of Strangers] (2006) and Dismas A. Masolo in "African Philosophy and The Postcolonial: Some Misleading Abstractions about Identity" (1997), but we may not be sufficiently disposed to accept Hountondji's, Appiah's and Masolo's views because the independent status of African philosophy coupled with a distinct African philosophical paradigm cannot be sufficiently removed by the "common" human race or philosophy given the differences in people's orientations, beliefs, practices, and modality for relationship. If a distinct African philosophy is rejected, the credence for African philosophy and a distinct African philosophical paradigm gained by philosophers like Moses Makinde, Odera Oruka, Ibout Emmanuel, Kwasi Wiredu, Didier Kaphagawani, etc., and radicals like Fanon, Cabral, Awolowo, Cesaire, Senghor, Nyerere, Mandela, Sékou Touré, etc., would amount to nothing. As literal as these philosophers may have defended the idea of a distinct African philosophy, it may still appear that doing African philosophy can be different from being an African philosopher: the reason is because what an African philosopher will be doing Exan be categorized as philosophy but may sometimes not be philosophy within the $\approx$ Africa socio-political and cultural studies. 
Given the attempt to redefine what qualifies one as an African philosopher, Appiah, while following Hountondji, contends that "by 'African philosophy' I mean a set of texts, specifically the set of texts written by Africans themselves and described as philosophical by their authors themselves" (APPIAH 1998, 109). This description, I think, knowingly withdraws the cruces of philosophical debate in post colonial black Africa. Appiah maintains that "as we have puzzled over whether philosophers who happen to share a continent should for that reason be classified together, we have wondered, too, what sorts of intellectual activity should be called "philosophy"” (APPIAH 1998, 110). Appiah's claim has helped in streamlining the qualification for doing African philosophy. However, Appiah's analysis renders Barry Hallen, Peter Amato, Robin Horton, M. P. More, Marlene Van Niekerk, and their likes, as aliens (unAfrican) because they are not of African descent or blood. Moreover, Barry Hallen, Robin Horton, Peter Amato, etc., have enormous written works on African philosophy. Fortunately, Appiah's analysis would render Segun Oladipo, Moses Makinde, Abiola Irele, Wande Abimbola, Seg un Gbadegesin, Julius Nyerere, Bolaji Idowu, Kwasi Wiredu, Peter Bodunrin, Moses Oke, and some other African philosophers of African descent as African philosophers. In any way that one may decide to look at it, it may be impossible to run away from tribal izing issues which ought to be tribalized or detribalized, if or when we consider or admit/accept what Appiah has said.

While trying to interrogate or re-interrogate Appiah's concession on "who is an African philosopher, or to redefine what qualifies one as an African philosopher", we are left with no choice than to start by seeking to clarify the following questions/issues: "who is an African?", "what is philosophy?" and "who ought to participate or write on contentious issues in African philosophy?" Perha ps, if we are able to understand the gravity of these questions or issues, we may conclude, in a way, that we have a clear understanding into the nature of how to do African philosophy, and what qualifies one to become an African philosopher. We must be careful in making sure that we are not employing the European paradigm to get a definition for philosophy, Africa, and an African philosopher. Similarly, there is the need to be careful that we do not get a European definition for who is an African. If John Stuart Mill had lived in Africa and wrote his work [On Liberty] in Africa, by implication, this work would by a social condition and academic criterion qualify as a work in African political philosophy. Perhaps, we may not want to provide an answer to this problem in that way. If we are to answer this question that way, it will suggest the following; would thousands of books published every day in Africa qualify as African philosophy? What ought to be the answer to the question who qualifies to become an African philosopher? No response or answer is devoid of Nome flaws.

It would be difficult to give an exhaustive or sufficient analysis of how we are to oxredefine what qualifies one as an African philosopher? What, to a great extent, may be required in setting out who becomes an African philosopher (which is not really about the exhaustive study of the historical facts of the past or the attribution of 
people with "African-ness in them"), may be a critical discourse in which reason and argument play a significant role. We cannot, however, characterize philosophy simply as the discourse that applies to our folk beliefs based on the techniques of specific logic and contextualized reason. If this is the case, academic philosophy, therefore, has done two things: (i) it has come to be defined by a canon of subjects as well as by its argumentative method, and (ii) it has turned out to be premised on how specific regions ought or should contribute to philosophy, as a universal discipline. This study may not be trying to assert that every culture does not have their views about what it is to have something so peculiar to that culture alone. Nor is it saying that no culture has specific social norms as different from the other. Every culture has had views about what 'it is' to have something different from others. Thus, "there is' in every culture a folk philosophy (which may involve having folk scientific-empirical orientation and facts), and implicit in that folk philosophy are all (or many) of the concepts that academic philosophers have made central to their study in the West, America, Africa, Asian, etc. Of course, there might not be in every society people who pursued a systematic critical conceptual inquiry, but at least in every culture, there is work for a critical philosopher, should he/she come or decide to do it.

Many factors could help in making a supposition that the task of knowing who is an African philosopher or who should be seen as African philosopher, very difficult. Many would, without exogenous intervention, take up the project of telling us who qualify to be called African philosopher. The exogenous intervention, in this regard, has left people with Western philosophical training to dabble into issues using the Western paradigm. That is, this exogenous intervention, through training, has unconsciously propelled the definition of an African philosopher using the Western paradigm. Because we have some Africans rooted, in at least, some degree of traditional cultures, and at the same time, we have some intellectuals trained in the traditions of the West, the latter makes African philosophy to face a special attention and problem. While some may choose to borrow the tools of Western philosophy to help define who an African philosopher should be, some others fails to borrow any leaf to define African philosopher. In any way that it may take, criteria according to Jonathan Chimakonam are needed to establish this purpose $(2015,102-110)$. But if traditional African scholars wish to pursue some conceptual inquiries in their own traditions, they are bound to do so with a highly developed awareness or consciousness of the challenges of Western training and ideas. The reason for this is because the Western paradigm has done a lot to redefine, re-structure, attack, propel, and address various concerns about the culture and beliefs of the "Others". But the acceptance of the definition of African philosophy and who becomes an African

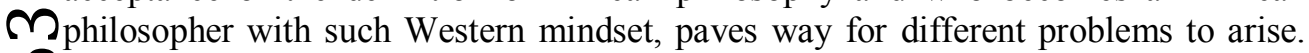
OSimilarly, such help or acceptance of the definition of African philosopher using the coWestern paradigm is not devoid of problems for the perceiver (Western

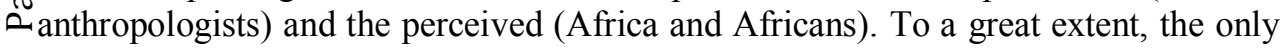
difference between philosophy in Africa and in other parts of Europe or America, 
should be the practice which philosophy entails, but the theory and practice of the works done in Africa and elsewhere is conceived as closer to the traditions that remain strong in those regions, countries or continents.

It is likely to concede, precisely, that whoever is to qualify as an African philosopher should remember to share, of course, a vocabulary of key words that belongs to the language of the philosophical tradition - truth and meaning, and such a vocabulary should become a referent and a tradition to follow in Africa or in any part of Africa that the author centers upon. Does this mean or suggest that African philosophy should not or ought not to be done using a foreign language? He re again, sufficiency or conclusiveness is difficult to establish or attain. This is because almost, except few African countries, were colonized and a particular foreign language has turned out to become part of their representative/respective identity. F or a person living outside Africa (e.g. a non-African) to become an African philosopher, this fuss may seem preposterous: what may be at stake, after all, may only be the right to label "philosophy". The claim to philosophy is the claim to what is most imp ortant, most difficult, and most fundamental anywhere in the world. And the enduring power of that claim is reflected in the commonest response from any inquisitive philosopher, be it French, or a German, or an Anglophone, a Portuguese, or a pure African in his/her nativity.

Another view is Appiah's. He asserts that, "orality is inconsistent with the philosophical tradition of writing, and it is also inconsistent with the demands of what Althusser calls "science": writing liberates the individual mind; "to make innovations that may shake the existing established ideas and even overthro w them completely" (APPIAH 1998, 129). As this study maintains, Appiah's position would help in identifying a logical, an epistemological, and a normative/moral framework which will make a meaningful addition to existing body of knowledge. African philosophy, therefore, is expected to transcend the level of orality and become literal. This helps in situating who qualifies to do African philosophy and who should become an African philosopher, as different (but not necessarily opposing) to/from who is to do African philosophy or who is an African. The ability to contemplate, write, the provision of logical basis for the idea to be asserted, argue coherently, and be scientific, Appiah implies, are the factors that makes an African philosopher.

However, in addressing the universal nature of the terms and concepts that are to be used and analyzed in philosophical discourse, the term 'African' may sometimes create an avenue for incoherence. In this respect, to associate "African" with philosophical or certain dispositions may not make any good for philosophical disposition. On the other hand, an individual (non-African by birth) who fails to show his expository, logical, critical, analytical and rigorous prowess cannot be said to be doing philosophy. An African who has virtually no clue about philosophical dispositions should not do African philosophy, either. And, an African philosopher Eowho is dogmatic about whatever he/she portends to be discussing as African ¿ philosophy should not be read or revered. To be able to qualify as an African philosopher, such scholar or individual should promote the myth of primitive African 
timelessness, obscuring history and change (which is the most common thing around in the world) with the zeal of transmitting them without dogma.

From the critical point of view, if we make an attempt to justify the positions of different philosophers concerning the rationale for the conflicting positions on who qualify as an African philosopher, such could be problematic. This may result to the notion that if we attribute "African" to whoever will or may qualify to become an African philosopher, then, we tend toward creating the notion of primitive savagery. How? If we use "African" to distinguish philosophers instead of the possession of the ability for philosophical disposition, having the philosophical tools and critical analysis, we will be creating an image of ethnicism in philosophy: where ethnicism makes philosophy to be carried out through an individual who is religious, dogmatic, and sentimental.

\section{The Interrogation of the Rationale for Different Conflicting Positions and the Justification of what qualifies One as an African philosopher}

The problem of who is meant to become an African philosopher and whether or not Africans by birth or blood have the sole right to do African philosophy may not have been conclusively resolved in this study. The reason is simple: the open-ended nature of philosophical disputes would be dealt with if the rationale, qualification and justification of who is an African philosopher is sufficiently resolved. Similarly, this study may not have sufficiently resolved who qualifies to be a philosopher, in order to make any issue in African discourse to qualify as universal. It has only attempted some reasons that are to be considered in knowing the nature of African philosophy and the justification of what qualifies one as an African philosopher.

For instance, Olubi Sodipo's and Barry Hallen's work entitled [Knowledge, Belief and Witchcraft: Analytic Experiments in African Philosophy] and Barry Hallen's work entitled [A Short History of African Philosophy] are works done within the context of African philosophy. The former is a critical explication and philosophical interrogation of the Yoruba analysis of ìmò (knowledge), ìgbàgbó (belief) àti (and) àjé (witchcraft) in the African epistemological study: while the latter is an explication of the subject-matter of African philosophy arising from the historical foundation of African philosophy, the specific factors that help one to do African philosophy, and theories of remaking Africa. Hence, it is preposterous to say that Barry Hallen is not an African philosopher. Furthermore, Olubi Sodipo's and Barry Hallen's work [Knowledge, Belief and Witchcraft: Analytic Experiments in African Philosophy] represents a classic example of a joint work done by an African and an American that both lectured at the department of Philosophy, University of Ife (now Obafemi Awolowo University, Ile-Ife, Nigeria). The reference that Sodipo's $\Omega$ and Hallen's paper has made to the Yoruba philosophy cannot be over-emphasized Obecause of the nature of such collaboration between two prominent African ophilosophers to create or attempt to resolve some pertinent issues/problems in $\widetilde{\Xi}$ Yoruba discourse on knowledge. 
The genuineness of what philosophy preaches should entail the will, knowledge and the technical ability to unravel certain problems within the framework of philosophy as an African would carry it out. The meaning of this lies in two things: the lived-experience; that is, the living experience of a philosopher on African soil and the content of what a philosopher writes concerning the African condition. Atimes, these two things may be done by whoever possesses the philosophical skill without recourse to racial essentialism, regionalism and tribalism. Doing philosophy in Africa may not be necessarily dependent on being an African. A non-African may possess the merit above an African to carry out a discourse or research in African philosophy on a certain problem, where his/her research may help in resolving a philosophical dispute, or provide relevant analysis into certain developmental problems facing Africa. It may follow that African philosophy ought not to be done entirely by Africans. By implication, the person who should qualify to do African philosophy may need to possess the required skills and relevant knowledge to be able to identify which aspect of African philosophical paradigm he/she is defending. It is noteworthy that a non-African who fails to understand the culture, language and philosophy of a particular part of Africa upon which he/she intends to carry out research should not do African philosophy. What will he/she write about when Africa remains unknown to begin with. Those who care to write on African philosophy should understand the nitty-gritty of the language to be used which is African, or the work should be understood from the African perspective.

As it is expected, a philosopher should be able to transcend the dogmatization of issues, but it does not mean that a philosopher cannot be influenced by culture. By provisional means, a philosopher need not be an offspring of a particular region to be able to participate in resolving philosophical disputes and issues. What is needed is the ability to use philosophical skills and analytic tools to discuss problems and provide the general solutions or recommendations that may aid the development of philosophy. This is provided that common ground knowledge in such discourse is evident. But to define African philosophy is to situate our definition within the African condition, articulate contextual relevance, gain currency and possess adequate information on any subject under consideration which only affects Africa. A philosopher in any part is expected to discuss issues and problems using the tools of philosophy (like logic, epistemology, meta-ethics, etc.,) to analyze discourses, problems, prospects and mortality.

The position of this study seems to differ from what Appiah, Masolo, and Hountondji have asserted. However, Kwame Appiah's assertion that "Africa's intellectuals have long been engaged in a conversation with each other and with Europeans and Americans, about what it means to be an African," is an indication that at the heart of these debates on African identity and a distinct African paradigm, Appiah says, "are the seminal works of politicians, creative writers, and philosophers cofrom Africa and her Diaspora" (1992, x). One implication of this view is the

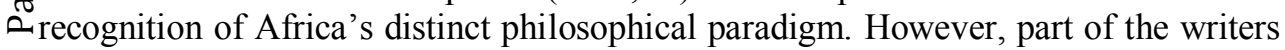
in the Diaspora, as Appiah maintains, is W. E. B. Du Bois. His discussion of Du Bois 
is a derivative of the notion that "the idea of an African race, is an unavoidable element in the discourse of the idea of Negro, and this racialist notion is grounded in bad biological, and worse ethical ideas, inherited from the increasingly racialized thought of nineteenth-century Europe and America" (1992, x). It is not that easy to highlight or understand Appiah's mind concerning who should participate in doing African philosophy. It can be derived from his thoughts that only Africans living within the continent or outside of African (Diaspora) should participate in doing African philosophy. Similarly, it is only an African who has the patent qualification to become an African philosopher. This is a result of the European invasion of the world of the Africans and the continent of Africa. Appiah's concession is that "being African is, for its bearers, one among other salient modes of being, all of which have to be constantly fought for and rethought" $(1992,177)$.

Appiah's view may be interpreted to mean that, central to contemporary life and the discourse on Africa, African philosophy and African philosopher, it is only Africans that recognize what African identity is all about. This claim can be further discussed using Ibout Emmanuel's view that "the question is whether African thought as it exists in Africa is the same sort of thing with thought as understood by the Western philosopher and we Europeans or educated Africans who share this culture" (IBOUT 2011, 211). The implication of both Appiah's and Ibout's frameworks is that, in doing African philosophy, it is only African intellectuals that can understand the nature of their defence for the identity that is solely African. Another implication is the way in which the African definition or view of thought may appear different from what others (say, Europeans or Americans) would see the identity and culture of the Africans. Thus, the 'identity' of Africa can only receive intervention or support from Africans and some others who only deem it worthy to lend a helping hand, since it will be difficult for a non-African to understand the emotional and the cultural struggles behind the need for an African Identity. However, while expressing his fear about Appiah's view because of his American background, Robin Horton asserts that "many social anthropologists or Europeans have been unfamiliar with the theoretical thinking of their own culture," while admitting that "even those familiar with theoretical thinking in their own culture have failed to recognize its African equivalents" (HORTON 1998, 181). His (Appiah's) response to Horton's fear makes him to posit that African unity and African identity through African philosophical discourse need securer foundation than race (1992, 176). Going by what Appiah opines, philosophy has nothing to do with a contextual discipline or a compartmentalized discourse; rather, it has to be seen using the general outlook or that its tools is meant for general analysis rather than the compartmentalized form of identity that Africa has reduced philosophy, identity and Nrace to. In Wiredu, Oruka, Kaphagawani, etc., views, this contextual Ocompartmentalization of philosophical discourse can only help in asserting the coindependence of African philosophy and who an African philosopher should be.

$\approx$ In a way that is different (but not essentially opposing) to Appiah, Chukwudi Eze $(1997,3)$ asserts using Lucius Outlaw's analysis that "to identify the features 
that make certain practices and legacies of persons who are situated in geographically and historically-socially diverse societies 'philosophy,' those features must be characteristic of though not necessarily unique to the persons as members of a dispersed race. This, Eze says, should be exemplified. The issue of race, as Eze contends, cannot be discounted, despite the fact that he (Eze) has not come to understand whether the notion of "geographic race" is the most pertinent of productive to be used in showing who to partake in African philosophy, and who ought to become African philosopher (1997, 3). Also, Eze points out in favor of Lucius Outlaw that he (Outlaw) explicitly insists that he will not subscribe to "biological or racial essentialism" $(1997,3)$. It is from this point of view that this study concedes in the following; for the fact it is only Africans (born within the geographical location of Africa, or the ones in the Diaspora) are the only eligible ones to partake in doing African philosophy and who are qualified to become African philosophers does not mean the creation of "racial essentialism". Though, this may represent an attempt to create, what Chukwudi Eze calls "Afr ica's distinct gene pool" $(1997,3)$, but as it appears, this study takes its departure from Barry Hallen's view, when he says that "philosophy in any cultural context is not likely to be the easiest subject in the world" (HALLEN 2002, 1). Through his discourse, Hallen may not, in any way, regard philosophy as essentially contextualized but that philosophy, when studied in different contexts is not an easy task. This is because of the nature of its essential characters which are rigor, analyticity, skepticism and criticism. However, as philosophy is done in Africa, which is to be done by both African intellectuals and foreigners who live on African soil, it may be the case that phil osophy would be seen from the African standpoints though with little, minimal, more, or no regard to how philosophy is done in Europe (with the empiricist and Continental traditions), America (pragmatist tradition), Asia (Oriental tradition), etc. In his footnote analysis, he posits that "I use the term "African" to refer to scholarship that is specifically concerned with the African continent and its cultures" (HALLEN, 2002, 4).

In this respect, the content and the aim of the views expressed by Horton, Hallen, and Eze can easily be antagonized or relegated using the interpretation of E. A. Ruch's concession. Given the existentialist analysis of the nature of African philosophy, E. A. Ruch posits that there is African philosophy (i.e., it exist); but what defines it is not the location or racial origin of its creators, but its concern with the way in which African peoples of the past and present make sense of their existence $(1981,17)$. How do we resolve the problem of the non-reliance on location or racial origin of the creators of philosophy, as explicated by Ruch? In his work "The Prefix "African" and its Implications for Philosophy in Africa", Samuel T. Segun's response or attempt is simple: "the laws of logic, the burden of axiology, the $\boldsymbol{O}_{\text {questions of metaphysics and the concerns of epistemology all transcend }}$ geographical boundaries": hence, "philosophy in Africa must not be seen as ogregionalized philosophy but rather a contribution to the subject matter and quest of ¿philosophy - the search for truth" (2014, 106 \& 118). The implications of Segun's assertions seem dire and severe. His assertions foreclose every avenue of regional 
participation in philosophy which has universal character and where ethnophilosophy is doomed to be purely African and lacking the essential ingredients because it is regarded as first-order level of discourse. This is reminiscent of Hountondji. It makes many thinkers to qualify as universal participants in philosophy without acknowledging their locational influence on the development of African discourse. It fails to see the influence of anthropological studies by Levy Bruhl having any influence on African studies whether cultural, traditional, sage, or ethnophilosophical. It sees colonialism as event which did not take place in Afr ica and which did not influence the characterization of philosophical studies and development in Africa. And five, it fails to see anything worthwhile in the post colonial search for a distinct African identity and the various impacts and influences which globalization, common human family and the idea of a common race have had and are still having on Africa. However, to a great extent, Uduma's response seems to differ from the views of Ruch and Segun. In his work "The Question of the "African" in African Philosophy: In Search of a Criterion for the Africanness of a Philosophy", Uduma posits that "African philosophy should be concerned with only a part of the African historical experience" $(2014,127)$, which by implication will have to cover centuries rather than the mere acknowledgement of the colonial and the anthropological necessities for the emergence of African philosophy. For him, "given the comprehensive nature of philosophy, we are inclined to the persuasion that a criterion for the Africanness of a philosophy ought to be derived from the totality of the African experience" $(2014,127)$. Uduma's claim, though appears appealing, it is not devoid of flaws. One, Uduma's claim attempts to ignore the fundamental problem of orality, which was fundamental to African thought prior to the Levy Bruhlian disposition. The problem of orality or oral literature has been pre-existing before the European missionary invasion of Africa. And two, Uduma's view pretend to ignore the cultural anti-revivalists like Hountondji, Masolo and others that an appeal to the cultural past in re-making Africa given the contemporary realities in science, technology, biotechnology, analytic philosophy, and various developments in logic (e.g., set theory, Binary theory, etc.,) should not even suffice because it will not lead Africa to anywhere.

A problem arises: if we use "African" to justify the rationale for qualification as an African philosopher, it may lead to substituting general analysis in philosophy for a detailed analysis of particular/contextual situations. This does not represent an avenue to conclude that Igbo metaphysics is the same as the Yoruba metaphysics or with Swahili or Bantu parts of Southern African, but in as much as we desire to deal with complexities, recognizing the tools of philosophical tradition helps in advancing philosophy at any level or region. To use the term "African" to/for/on whoever may desire to write meaningfully and argue coherently (not anthropologically) in African Ophilosophy, is to primitively recognize the usage of the word 'tribe'. This may not odhelp in formalizing what ought to become part of the issues to be addressed in aphilosophy, be it from the African, European (British or Continental), American, or 
Asian point of view. On the other hand, the continuous development of African philosophy may not be aided.

However, it is not sufficient to disclaim the views of some skeptics like Bruhl, Hountondji, Appiah and Masolo with respect to the unreality of distinct philosophical tradition in Africa, but it is pertinent we assume that a philosopher need not necessarily be of African descent or race before he/she can participate in the discussion of relevant issues in African philosophy. The view that an African philosopher need not be an African by geographical origin has particularly been stressed by Chimakonam in suggesting 'logic' as the grand criterion a discourse has to meet before it could qualify as African philosophy (2015, 104-105). Chimakonam describes what he calls Hountondji's dilemma as any suggestion (such as implied by Hountondji) that recommends that a true African philosophy must be universally applicable and concedes again that it can only be done by a native African (2015, 104). Amato appears to think in this direction when he says that "the development of African philosophy is moving the discussion well beyond the potential danger of confinement within improper conceptions of raciality, not simply attacking racialized thought, but via constitutive activities of different contributions" (AMATO 1997, 725). To admit it, this is also true, because some African scholars have participated in the discussion of some issues in the Western (British, Continental or pragmatic) philosophy, while some are still participating.

\section{Conclusion}

Becoming an African philosopher and being able to do African philosophy, for some philosophers may be as a result of the following; namely, "biologism or essentialism" and "distinct gene pool". These terms may have been recently developed to aid philosophical orientation in Africa but the consequence of how these terms will help the genuine development of African philosophical disposition appear debatable. Since the philosophers' laboratory is their thought, it suffices to say that philosophers whether of African descent or race, or not, they should be able to use the tools of philosophy to discuss problems, prospects, issues and mortality of African philosophy provided that they understand how to go about it. The reality of entertaining the existential status of African philosopher in the way that most African countries are French speakers, Anglo-phone or Portuguese speaking nations, may portend problem from a genuine philosophical development. On the one hand, it is expected that a philosopher who is not of African descent or race but could write, speak or use any African language, should be able to discuss whatever lies within the African philosophical discourse using the native African languages or the language given to them as a result of colonization. However, in order to elude the problems of an author's cultural lineage or descent of being "African" and the content of a work discussing "African" issues, we have to look for a synthesis of which the author and othe issues discussed in a work must reflect the discussion of problems relating to $\approx$ African conditions. To a great extent, arguments whether in support or against the ontology and the subject-matter of African philosophy and the qualification to be an 
African philosopher remain inconclusive and not time lapsing. The reason may be that whenever a person is writing and the tools of philosophy (analysis, criticism, rigor, skepticism, etc.,) are applied, the issue of ethnic sentiments is taken for granted.

However, Makinde's opinion that "the teaching of African philosophy is generally poor when compared to the teaching of Western philosophy" cannot be discarded. This is so because many of the African philosophers who write on African philosophy as a controversial subject do not teach or know anything about it. They just talk about it, or write on the talks about it as a refreshing exercise using their Western philosophical understanding" (1987, 229). What he (Makinde) attempts to assert is that, inasmuch as the growth of philosophy is becoming poorer and weaker every time in Africa, to foresee the growth of philosophy as we would have wanted it in Africa will be impossible. How can philosophy grow in Africa? Its growth may sometimes be as a result of allowing others (not of African race, tribe or descent) to participate in developing it, just as Barry Hallen, Robin Horton, George Chartalian, M. P. Moore, Bruce Janz etc., have done in the past. Allowing the exercise, participation, growth and development of philosophy to be limited to Africans in African philosophy may not allow the following to be enhanced: African philosophy, Africa's quest for development, and a distinct African philosophical paradigm. However, the contingent nature of the above view may not be able to absorb or relish the concession of this study. That is, anyone who cares to write on African philosophy should understand the nitty-gritty of something greater than the language to be used, the individual have to become an African after the philosophical study, or the work should be solely representing the African perspective in the universal/global enterprise called body-philosophy.

\section{Relevant Literature}

1. AMATO, Peter. "African Philosophy and Modernity," [Postcolonial African Philosophy: A Critical Reader, CHUKWUDI Eze Ed.], 1997. Blackwell Publishers Inc: Cambridge, MA. 71-99. Paperback.

2. APPIAH, Kwame. "Ethnophilosophy and its Critics," [The African Philosophy Reader, PIETER Coetzee and ABRAHAM Roux Eds.], 1998. Routledge: London. Paperback.

3. —_. "Illusions of the Race," [In My Father's House: Africa in the Philosophy of Culture], 1992. Oxford University Press: New York. Paperback. 
4. BIAKOLO, Emevwo. "Categories of Cross-Cultural Cognition and the African Condition," [The African Philosophy Reader, PIETER Coetzee and ABRAHAM Roux, Eds.], 1998. Routledge: London. Paperback.

5. BÓDÚNRÌN, Peter. "The Question of African Philosophy," [African Philosophy: An Introduction to Third Edition, RICHARD Wright Ed. ],1984. University Press of America: Lanham. Paperback.

6. BRUHL, Levy. [Primitive Mentality], 1975. Harper \& Row: New York. Paperback.

7. CHIMAKONAM, O. Jonathan. "The Criteria Question in African Philosophy: Escape from the Horns of Jingoism and Afrocentrism", [Atuolu Omalu: Some Unanswered Questions in Contemporary African Philosophy, Jonathan O. Chimakonam Ed.], Pp101-123, 2015. University Press of America: Lanham. Paperback.

8. - - [The 'Soul' of the Primitive, EDWARD Evans-Pritchard Ed.], 1965. Allen \& Unwin Ltd: New York. Paperback.

9. EZE, Chukwudi, Ed. [Postcolonial African Philosophy: A Critical Reader], 1997. Blackwell Publishers Inc: Cambridge, MA. Paperback.

10. HALLEN, Barry. [A Short History of African Philosophy], 2002. Indiana University Press: Bloomington, IN. Paperback.

11. _. and SODIPO, O. [Knowledge, Belief, and Witchcraft: Analytic Experiments in African Philosophy], 1997. Stanford University Press: Palo Alto, CA. Paperback.

12. HORTON, Robin. "African Traditional Thought and Western Science," [African Philosophy: An Anthology, CHUKWUDI Eze Ed.], pp181-192, 1998. Blackwell Publishers: Oxford. Paperback.

13. HOUNTONDJI, Paulin. "Knowledge as a Development Issue," [A Companion to African Philosophy, KWASI Wiredu Ed.], pp529-537, 2006. Blackwell Publishers Ltd: Malden, MA. Paperback.

14. IBOUT, Emmanuel. "On Delimiting African Philosophy and the Equalization Scheme," [Oginni: A New Journal of African Studies], Vol 4. 2011 pp210225. Web. 
Filosofia Theoretica: Journal of African Philosophy, Culture and Religions

15. JANZ, Bruce. [Philosophy in an African Place], 2009. Lexington Books: Plymouth, UK. Paperback.

16. KAPHAGAWANI, Didier. "What is African Philosophy," [The African Philosophy Reader, PIETER Coetzee and ABRAHAM Roux Eds.], 1998. Routledge: London. Paperback.

17. MÁKINDÉ, Moses. [African Philosophy: The Demise of a Controversy], 2010. Obafemi Awolowo University Press Ltd: Ile-Ife. Paperback.

18. — . "Teaching Philosophy in Africa," [Teaching Philosophy],. pp227-238, Vol 10. No 3., 1987. Web.

19. MASOLO, Dismas. "African Philosophy and the Postcolonial: Some Misleading Abstractions about Identity," [Postcolonial African Philosophy: A Critical Reader, CHUKWUDI Eze Ed.], 1997. Blackwell Publishers Inc: Cambridge, MA. Paperback.

20. MORE, Mabogo. "Outlawing Racism in Philosophy: On Race and Philosophy," [The African Philosophy Reader, PIETER Coetzee and ABRAHAM Roux Eds.], 1998. Routledge: London. Paperback.

21. NIEKERK, Marlene. "Understanding Trends in African Thinking," [The African Philosophy Reader, PIETER Coetzee and ABRAHAM Roux Eds. ], 1998. Routledge: London. Paperback.

22. ÒKÈ, Moses. "Cultural Nostalgia: A Philosophical Critique of Appeals to the Past in Theories of Re-Making Africa," [Nordic Journal of African Studies], Vol 15. No 3. 2006. Web.

23. OLÁDÍPÒ, Ségun. "The Debate on the Idea of African Philosophy," [Thinking about Philosophy: A General Guide, SEGUN Oladipo Ed.], pp6077, 2008. Hope Publications: Ibadan. Paperback.

24. OYĖDOLÁ, David. "The Culture-Oriented Bias of African Philosophical Inquiry," [Filosofia Theoretica: Journal of African Philosophy, Culture and Religions], pp62-80, Vol 3, No 2., 2014. Paperback.

25. RUCH, E. A. and ANYANWU, K. C. Eds. [African Philosophy: An Introduction to the Main Philosophical Trends in Contemporary Africa], 1981. Catholic Book Agency: Rome. Paperback. 
26. SEGUN, T. Samuel. "The Prefix "African" and its Implications for Philosophy in Africa," [Filosofia Theoretica: Journal of African Philosophy, Culture and Religions], pp106-123, Vol 3., No 2., 2014. Paperback.

27. TÁíWÒ, Olúfémi. "Post-Independence African Political Philosophy," [A Companion to African Philosophy, KWASI Wiredu Ed.], pp243-259, 2006. Blackwell Publishing Ltd: Malden, MA. Paperback.

28. UDUMA, Uduma. "The Question of the "African" in African Philosophy: In Search of a Criterion for the Africanness of a Philosophy," [Filosofia Theoretica: Journal of African Philosophy, Culture and Religions], pp127146, Vol 3., No 1., 2014. Paperback.

29. WIREDU, Kwasi. "How not to Compare African Traditional Thought with Western Philosophy," [African Philosophy: An Anthology, CHUKWUDI Eze Ed.], pp193-199, 1998. Blackwell Publishers: Malden, Mass. Paperback.

30. -... "On the African Orientation in Philosophy," [Second Order], pp3-13, Vol 1. No 1., 1972 Paperback. 